\title{
The Function of Humor Applied in Margaret Cho's Stand-Up Comedy: PsyCHO
}

\author{
Anindita Dewangga Puri \\ aninditalucia@gmail.com \\ Faculty of Cultural Science, Universitas Gadjah Mada \\ F.X. Risang Baskara \\ rbaskara@swinburne.edu.my \\ English Letters Department, Universitas Sanata Dharma
}

\begin{abstract}
This article discusses the function of humor in Margaret Cho's Stand-Up Comedy entitled PsyCHO. The aims of this research are to explain the humor function applied by Margaret Cho in creating humor situation in her stand-up comedy. The data in this research are oral data which is transcribed into written form. This study uses a qualitative descriptive method. According to the research in the stand-up comedy entitled PsyCHO, the researchers found that Margaret Cho tends to use humor function to create solidarity with the audiences. This is dominated by sharing strategy which is often conveyed by Cho in her stand-up comedy.
\end{abstract}

Keywords: humor, stand-up comedy, pragmatics, jokes

\section{Introduction}

Humor is closely related to life community. The existence of humor in society is not only used to make people laugh, but also can be used to release a tension. As stated by Wijana (2003) in his book entitled Kartun: Studi tentang Permainan Bahasa, humor is kind of wordplay which can stimulate people to laugh. It is also in accordance with the definition of humor by Ross (1998) that humor is everything that makes someone laugh. As one of the linguistics phenomena, the use and variation humor are growing over time. One type of humor that does exist in society is stand-up comedy. According to the Oxford English Dictionary (in Double, 2014), stand-up comedy is defined as a comedian who acts in front of the audience while telling funny things. Stand-up comedy itself appeared since the $19^{\text {th }}$ century in America and Europe. America became the pioneers for some famous comics such as Sarah Silverman,
Robin Williams, Christ Rock, Ellen Degeneres, Margaret Cho, and others. Each comic has its own characteristics in delivering its comedic materials. For example, Ellen Degeneres whose jokes have a topic related to gay and lesbian, George Charlin who often touches on a religious topic, and Margaret Cho whose jokes are about racism, politics, women, and sex.

This research uses one of American female stand-up comedy that is Margaret Cho. The researches choose female stand-up comedy because there has been little research examining stand-up comedy performed by a woman, especially in terms of linguistics. Most of the researches conduct research on stand-up comedy performed by male comics. Moreover, some researches such as Lakoff and Goodman (in Hay, 2000) said that women have no sense of humor rather than men. They are not suitable for telling humor. Margaret Cho herself is well-known as a 
female comic who dare to speak out about racism, politics, women, and all about sexual behavior. She was born on December 5, 1968, and grew up in San Francisco. Cho's childhood passed by unusual circumstances. She experienced several times sexual violence, abuse, torture against herself, and racism made her poured all her bitterness into the jokes. Cho also one of female comics who put criticism and satire in her material bravely. As stated by Chun (2004), that Cho tends to issue mocking Asian in her comedy material. PsyCHO is one of the stand-up comedies performed by Margaret Cho in 2015. This stand-up comedy contains jokes about police brutality, racism, and violence against women in America. In this stand-up comedy, Margaret Cho tries to convey her madness and anger into humor.

\section{Method}

This research uses a qualitative descriptive method. Stand-up comedy employed by Margaret Cho becomes the object of this study. The main source of this research is the stand-up comedy entitled PsyCHO. The researches downloaded the stand-up comedy video from www.youtube.com. This research is carried out in three stages (Sudaryanto, 1993). First is data collection, the second is data analysis, and the last is the presentation of the results of data analysis.

The researchers collected the data by using simak bebas libat cakap technique (Kesuma, 2007, p. 44). The researchers downloaded, listened and observed the video without being directly involved in the conversion process. After obtained the video, the data is transcribed as well as adapted to the PsyCHO video subtitle found on www.subscene.com. In addition, the researchers also divided the stand-up comedy data into three parts: opening, core which was consisted into several bits, and closing. Then, each of the sentences on the data is marked by numbers in order to make the researchers easy to analyze the data.

This research used a contextual method in which this method promoted speech situation consisting of a speaker, hearer, place, speech time, and all of these were associated with linguistics phenomenon (Sperber and Wilson, in Wijana 2014). According to the bits in the stand-up comedy, the researchers analyze the humor function presented by Margaret Cho in PsyCHO. The contextual method was used by the researchers to analyze the function of humor. The result of the data analysis was presented in formal and informal methods (Sudaryanto, 1993). The obtained data were written into table form by using a formal method, and the explanation of the data is written by using an informal method.

\section{The Functions of Humor}

Humor also has a various function besides aiming to make people laugh. According to Hay (2000), humor has three functions that are solidarity function, power function, and psychological function. The solidarity function emphasizes the function of humor to create solidarity between members in a group. There are several strategies in this solidarity function. First, to share by expressing things about the speaker including sharing sensitive things. Sharing sensitive things also indicates that a comedian believes to the audience so that it can increase a sense of solidarity. Second, to highlight similarities or to share the same experience. According to Ziv (in Hay, 2000) humor in this strategies aims to share ideas, interests, and other similarities between speakers. Third, to clarify and maintain boundaries within a particular group. This strategy strengthens the standard accepted and agreed by the particular group. The last, to tease to strengthen solidarity, express the relationship, and maintain the strength of the teaser (Radcliffe \& Brown in Hay, 2000). This can be done by teasing and insulting each other, such as jokes about a relationship, the routine life of an individual, and insulting others who are already known.

The power function has several strategies. This type of humor intentionally has the purpose of degrading other people or sending an aggressive message (Martineau in Hay, 2000). The first strategy is to control for example humor where comedian tries to control the audiences to do something. Second, to respond to the existing of the social phenomena. This strategy comes from the 
Literature

Vol. 19 No. 1 - April 2019

(online)

facts that occur and is something judgemental. Third, to tease by attacking someone else's personal or by making criticism for other things. In addition, mocking, looking down on others, and insulting is included in this strategy.

The psychological function in humor has several strategies such as to defend by identifying the weakness of the comedian before anyone else does it. Every humor that implements this function has the purpose of protecting the comedian from criticism that may come. To cope with a contextual and noncontextual problem. Humor in this type serves to overcome problems that arise during a conversation, while humor to cope with noncontextual problems such as problems for survival that are generally felt by humans as living things, such as humor about pain, something that makes depression, and something that frightens. In addition, in terms of psychology according to Martin \& Ford (2006), humor also has a function to release pressure, suffering, disappointment, anxiety, and to convey taboo things that do exist in society.

\section{Discussion}

Every humor that is raised by the comedian must contain certain intentions or functions. According to the data that were analyzed, Margaret Cho fulfills the three functions of humor in the stand-up comedy entitled PsyCHO.

\section{Solidarity Function}

\section{a. To share}

This strategy can be done by expressing things about the speaker and even expressing sensitive things about the comedian. The aims of this strategy are to make the audience get to know more about the life of the speaker.

\section{(Bit 4)}

103 But I think that, like, it's-it's fierce to be that Asian, you know.

104 It's like we're talking about our heritage and it's awesome, you know?
ISSN: 1410-5691 (print); 2580-5878

105 But I-I like to sort of feel like exotic, you know?

106 I love... I love white dick. (laughter)

107 You know? I do.

108 I love... I love some white dick.

109 It makes me feel exotic, you know, like

I want to put a, I want to put a

flower in my hair, like... (laughter)

110 (Korean accent): "They remind me of my homeland."

111 Love that.

112 White dick is not... you know, it's not too big so it doesn't stretch me

out. (laughter)

The data in bit 4 above illustrates the use of humor to strengthen solidarity. The context of this utterances is about Asians, especially what Margaret Cho likes as an Asian. The sharing strategy is used by Cho by telling the audience what she likes, that is a white penis. Cho clearly stated that white penis could make her felt more exotic. This is included the humor function to strengthen solidarity by expressing about Cho's life including sensitive matters.

\section{b. To highlight similarities experiences}

This kind of strategy can be done by sharing the same experiences in a group. This is also explained by Cho in her stand-up comedy.

\section{(Bit 2)}

59 It's weird, that I think that white people, sometimes...

60 I think white people want to tell Asian people how they should feel

about race because they're too scared to tell black people. (laughter)

\section{(pause)}

61 You know, we have less melanin, we're not as intimidating, we're less

likely to "shut it down." (laughter)

The data above reveals on how white people are afraid to talk about race issue with black people. It is actually felt by Asians too, how they are afraid to talk about race in front of black people. This happens because of the dark history between Asians and black people 
in America. According to the utterance number 60, it is seen how Margaret Cho shared the similarities as Asian with white people because basically, they are all afraid of talk about race issue with black people.

\section{c. To clarify and maintain boundaries within a particular group}

One of the strategies to keep boundaries or norms in a group is through humor. Here is how Cho strengthens solidarity by telling that Cho as Korean has violated the Korean culture.

\section{(Bit 29)}

947 And, uh, so, uh, K-Koreans are very, uh, they're-they're really against

tattoos, it's very taboo for Koreans to have tattoos, because during the

Korean War, everything was destroyed and then rebuilt by organized

\section{crime.}

948 And the way that the organized criminals always recognized each

other was through their tattoos.

949 So it's really controversial.

950 And so I go to the clothing-optional Korean spas in Los Angeles,

which are not just clothing-optional.

951 Everybody's just naked.

952 You know, everybody's just naked and I'm just naked, with my tattoos,

and, you know, walking around and Korean people are giving me dirty

looks which is hard to tell.

953 It's hard to tell when a Korean is giving you a dirty look. (laughter)

954 You know, the... (laughter)

955 So I felt self-conscious.

956 So I went into, like, a sauna, you know,

by myself, and I'm just sitting

there in the sauna, naked, watching bigscreen TV, just watching golf.

957 And the manager comes in and she's fully clothed and she's like, "Uh,

could I talk to you out here? It's really hot."

958 And I was like, "Okay."

959 And so I was standing outside and she goes, "I hate to tell you this,

but you are really upsetting people here with your body. (laughter)
The data on bit 29 tells us how Korean have certain norms in their society. The use of tattoos in Korea is very taboo. It is because tattoos were once a symbol of organized criminals in Korea, so Koreans never wear tattoos. However, as a Korean, Cho precisely violates this norm. It became an experience for her when she was in a Korean spa in America. She was naked at the spa and many Koreans gave her dirty looks, even the manager of that spa asked Cho to wear her clothes because her body was filled with tattoos. It was an unpleasant experience for Cho because basically there are some rules that must be fulfilled when entering a particular group.

\section{d. To Tease}

This strategy is intended to strengthen solidarity in a relationship. Usually, people tease one to each other because they have a close relationship one to others.

\section{(Bit 5)}

133 Sometimes it's a little bit... Like, you know, it's like Asian women are too beautiful.

134 Like, they're just so beautiful, it's like nobody can compare.

135 You saw... you see good, like...

136 Sometimes there's a good couple, like, a beautiful Asian woman with,

like, a beautiful white man, and, you know, it's nice.

137 But sometimes you'll see, like, a really beautiful Asian woman, and

she's with the most fucked-up face, broke down, busted white man, and I'm

just, like, "Bitch, are your eyes that small?" (laughter)

The data in bit 5 above describes the solidarity function conveyed by Margaret Cho by teasing Asian woman. At first, Cho told the audience that the Asian woman was very beautiful and there was no one can match with an Asian woman. Cho herself was very impressed when there were Asian women dating a good white man. However, Cho also told the audience that sometimes there were Asian women who were actually beautiful but she chose to date white men whose faces were not handsome. The data number 137 
Literature

Vol. 19 No. 1 - April 2019

(online)

makes the audience laugh. By saying "Bitch, are your eyes that small?" Thus, Cho taunts that Asian woman who has narrow eyes.

\section{Power Function}

The power function in stand-up comedy emphasizes the power of a comic to be able to control the audience in order to create the goals desired by the comic. In addition, the power function can also be in the form of criticism, satire, or ridicule for others.

\section{a. To foster conflict}

Fostering conflict can be done by a comedian by sending an aggressive message or by degrading others.

\section{(Bit 29)}

965 And I-I was a little bit I didn't know what to say.

966 And, you know, the ladies are looking at me and me, finally, I just said,

"Uh, do you know who I am?"

967 And her eyes went from my enormous bush to my face and she

realized.

968 "Oh, my God! You're Margaret Cho!

I'm a really big fan! I've been to

your shows. I think you're amazing! But you still have to put your clothes

on." (laughter)

969 So I was like, "All right, but this is wrong and you are gonna be

sorry."

970 Then I just walked away. (laughter)

(imitates noisy dripping)

The context of the bit above is about Cho's inconvenience because officers and all spa visitors at that Korean spa give dirty look to Margaret Cho. It is because they do not like seeing Cho's body full of tattoos. In the utterances number 969 and 970, Cho sends an aggressive message in a threatening manner to the manager of the spa because of her unpleasant behavior. It makes the audience laugh in that stand-up comedy.

\section{b. To control}

ISSN: 1410-5691 (print); 2580-5878

This strategy in humor can be interpreted as controlling a person's behavior. It also forces people to do something. Here is an example of the power function in Cho's standup comedy with a strategy of controlling the audience.

\section{(Bit 18)}

550 Girl... girl, when did you see a pussy?

551 What... what happened, though?

(asking to the audience)

552 It was my friend's mother. (the audience said)

\section{Oh, no! (audience groaning)}

554 Wait... (laughter)

555 Wait, why?

556 Wait, oh, no, no, yeah, no, no.

557 Wait for a second, wait for a second, wait for a second, wait for a second, wait for a

second, wait a second.

558 What is it?

559 You ate the pussy? I mean and your boyfriend is like, "Oh, God."

(laughter)

560 'Cause it's almost like you ate the pussy by proxy. (laughter)

In the data above, it can be seen on how Cho attempts to create humor on the stand-up comedy by asking the audience directly about the vagina, how was the last time one of the audiences saw a vagina. One of the audiences answered Cho's questions, continued by other audiences' laughter because one of that audiences answered that he saw a vagina from his mother's friend. The power function to control others can be seen through bit 18 on how Margaret Cho as a comic can freely control the audience's behavior to answer her question. The audience answered Cho's question without hesitation and it made the other audiences laugh.

\section{c. To respond to the existing of the social phenomena}

Sometimes certain social phenomena that arise in society can be used as a material to create humor situation. The function of this strategy is sometimes judgmental according to the fact that occurs in society. 
(Bit 25)

810 So we will go and we will teach Boko Haram a lesson about women and education.

811 So, yeah, I think I want to put together a crew.

812 I want Michelle Rodriguez.

813 Uh, I want Ronda Rousey.

814 I want... I want the scary Japanese bitches from The Grudge and The

Ring.

815 You know, the... (laughter) (pause)

816 I want Cagney and Lacey.

817 I want Ruth Bader Ginsburg.

818 I want Courtney Love.

819 You know... (laughter)

820 You know Courtney Love cannot wait to behead somebody.

821 Aah! Judge Judy.

822 And Bruce Jenner.

823 It'd be so good, It'd be so good. (laughter) (pause)

In this strategy, Margaret Cho conveyed about social phenomena that had occurred in the society that was Boko Haram. Boko Haram had kidnapped for about 250 students from Nigerian and all of them are women. Margaret Cho made this phenomenon as a joke because she really did not want those students kidnapped by Boko Haram only for their importance. They still had an opportunity to continue their education. The humor material related to this social phenomena was conveyed by Cho as a distinctive feature in her stand-up comedy materials. It is because Cho is famous as a female stand-up comedian who dares to criticize social and political issues and other matters concerning race and sexuality.

\section{d. To Tease}

This strategy can be done by attacking others, taunting, satirizing, and making criticism for others. Here is an example of data where Cho uses this strategy to make humor situation.

\section{(Bit 30)}

1005 I was on the plane to go to England and I was on the plane and I was walking on the plane and Patti LaBelle was sitting in the first class.
1006 Patti LaBelle sees me and she goes, "Oh, hell, no!" (laughter)

\section{(pause)}

1007 "Oh, hell, no! You're gonna stay on your side of the plane cause you

crazy!" (laughter) (pause)

1008 Then her eyes just followed me for the entire flight.

1009 Like like she was in a painting in a haunted mansion. (laughter)

The data in bit 30 shows the power function in Cho's stand-up comedy by satirizing others. The utterances number 1005 until 1009 was about Cho's journey to England and she met Patti LaBelle. Patti LaBelle is an American artist and singer. She also a black descent. Margaret Cho brought Patti LaBelle into joke material because of the dark history between Korean-American and black people. Black people hate Korean Americans. It is represented in utterances number 1006 and 1007 that showed Patti LaBelle hatred to Cho, even Labelle insulted Cho as a crazy woman. The data in bit 30 also shows on how Margaret Cho as a comic in the stand-up comedy has the power to create a humorous situation in any way, including by insinuating on how black people treat against Korean Americans.

\section{Psychological Function}

The psychological function in conveying humor is closely related to release the tension in a person.

\section{a. To defend}

This strategy aims to create a defense for comics by conveying their weaknesses to protect themselves or free themselves from possible criticism.

\section{(Bit 12)}

343 You know, I'm impressed by it, because of Asian women...

344 We've got a lot, but we don't have the ass.

345 I don't have... I-I don't... 346 I have, like, a fold. (laughter) 347 Fold, not an ass. 348 I-I just don't have, uh, that part. 
Literature

Vol. 19 No. 1 - April 2019

(online)

349 You know, I have a fat vagina. (laughter)

349 Flat ass, fat vagina.

350 That's... that's never gonna be in fashion. (laughter) (pause)

351 There are no songs about that. (laughter) (pause)

352 It's-it's where I carry my weight.

353 You know, I don't...

354 I have no junk in the trunk.

355 I have junk under the hood. (laughter) (pause)

The data in bit 12 shows how Cho defended by identifying the weaknesses she had. Actually, Asian women are beautiful but Margaret Cho does not represent as a beautiful Asian woman. It can be seen through the utterances number 345 until 355, where Cho explained that she did not have a good buttock but her buttock like a fold that caused her buttock seemed like flat buttock. She also had a fat vagina. This is the strategy that Cho had to identify her weaknesses in her standup comedy and it made the audience laugh.

\section{b. To release tension}

Releasing tension in psychological function can be done by releasing suffering, pressure, and anxiety that feels by a person. Here is an example of how Margaret Cho uses this strategy in her stand-up comedy.

\section{(Bit 26)}

824 I like thinking about my, my bucket list.

825 Like, if I have a bucket list it would be: first, I want to go to India and

throw acid in the face of every man who ever threw acid in the face of a woman.

826 That would be great.

827 I'd feel really good!

828 Just to Wicked Witch some motherfucker who did that, it'd just be great.

829 Then I want to go to Russia, I want to kill every gay-basher that I ever saw on the Internet, um...

830 I want to come back here, I want to kill every child molester, every
ISSN: 1410-5691 (print); 2580-5878

rapist, and anybody who unnecessarily abused an animal.

831 Oh, Yeah.

832 Michael Vick's fucking dead.

833 Fucking dead.

834 Uh, a whole bunch of Catholic priests are going down. (laughter)

835 Like, Jerry Sandusky, fucking dead.

836 All the-the fucking people that tried that killed Matthew Shepard,

fucking dead.

837 And I-I are serious.

Bit 26 above shows how Margaret Cho released her deepest hatred and desire by pouring it into humor. The utterances number 824 until 836 showed that Cho hated a man who was arbitrary to a woman, child molester, rapist, Michael Vick as a suspected animal torturer, Jerry Sandusky a perpetrator of rape and sexual violence against children, and criminals who tortured and killed a student named Matthew Shepard. The utterance number 837 showed Cho's response to these criminal cases. Humor which material was raised from criminal cases was conveyed as a form of Cho's anger toward deviant things that actually happened in this world.

\section{c. To convey taboo things}

A strategy that is carried out in the psychological function of humor is by conveying taboo matters. Not everyone can talk about this taboo in a serious scope, therefore another alternative to discuss taboo matters is by using humor.

\section{(Bit 9)}

217 Her funeral was hard.

218 It was, it was all comedians there.

219 Everybody was crying.

220 It was here in New York City, and everybody was crying, crying.

221 It was a big temple.

222 Just everybody, every comedian you know is there, and it was so hard, 'cause we were all crying so much because we had lost our mother.

223 And Howard Stern delivered the eulogy. 
224 And he was crying, he was crying, which is sad to see...

225 So sad to see him crying.

226 And finally, through the tears, he managed to speak, and he said, (in

a deep voice): "Joan... Rivers... had such... a dry... pussy." (laughter)

(pause)

227 "Her pussy... was so dry, it was like a sponge."

228 "And when she would get in the bathtub, all the water would get

absorbed in there. (laughter)

229 Like... (imitates water whooshing)

230 And Joan used to say that if Whitney Houston had as dry... (laughter)

a pussy... as Joan... she would still be... alive... today. (laughter) (pause)

Bit 9 is one of the examples Margaret Cho uses taboo things in her stand-up comedy. This incident was based on a true story at the funeral of Joan Rivers, one of the famous comedian in America. Howard Stern, who was in charge of giving a speech at that time, deliberately mentioned the dry vagina of Joan Rivers. Actually, that kind of joke is very rude if it is expressed during mourning situation. However, Stern had a reason why he did it at the funeral, it was because he did not want the attendance to be too sad with Joan's death. This taboo thing that was told by Cho actually made the audience laugh.

\section{Conclusion}

According to the research in the stand-up comedy entitled PsyCHO, the researchers found that Margaret Cho tends to use humor function to create solidarity with the audiences. This is dominated by sharing strategy which is often conveyed by Cho in her stand-up comedy. Sharing strategies are carried out by expressing things about Cho's life, whether it is sensitive or not. In the PsyCHO stand-up comedy, Margaret Cho often shared her life story from the first Asian family sitcom she starred in, revealing on how her body is fat and contrary to Asian women who are famous for their beauty, sharing ideas and opinions about what is on Cho's mind.

In addition, through the comedy, Margaret Cho is able to freely express sensitive things that happen to her so that the audience can get to know Cho personally. The function of humor in this stand-up comedy is dominated by solidarity function with sharing strategy as the most used strategy. This humor contains Cho's madness and anger towards her experiences and cases that occur in this world. Margaret Cho tries to make this tragic situation into humor and share them with the audience so that the audience can get to know various aspects of Cho's life.

\section{References}

Double, O. 2014. Getting the Joke: The Inner Workings of Stand-up Comedy. London: Bloomsbury.

Hay, J. 2000. "Function of Humor in the Conversation of Men and Women", Journal of Pragmatics 32, pp. 709-742

Kesuma, T.M.J. 2007. Pengantar (Metode) Penelitian Bahasa. Yogyakarta: Penerbit Carasvatibooks.

Ross, A. 1998. The Language of Humor. New York: Routledge.

Sudaryanto. 1993. Metode dan Aneka Teknik Analisis Bahasa: Pengantar Penelitian Wahana Kebudayaan secara Linguistik. Yogyakarta: Duta Wacana University Press.

Wijana, I.D.P. 2003. Kartun: Studi tentang Permainan Bahasa. Yogyakarta:

Penerbit Ombak.

Wijana, I.D.P. 2014. Wacana Teka-Teki. Yogyakarta: Penerbit Ombak. 